\title{
ISOLATION AND IDENTIFICATION OF NEW STRAINS OF LACTIC BACTERIA FROM THE MICROBIOM OF YOUNG CARP FISH
}

\author{
Tekebayeva Zh.B. ${ }^{1}$, Bissenova G.N. ${ }^{1}$, Dossova A.D. ${ }^{1}$, Urazova M.S. ${ }^{1}$, Shevtsov \\ A.B. ${ }^{2}$, Temirkhanov A.Zh. ${ }^{1}$, Rakisheva A.K. ${ }^{3}$, Abzhalelov A.B. ${ }^{1}$, Sarmurzina \\ Z.S. ${ }^{1}$ \\ ${ }^{1}$ Republican Collection of Microorganisms \\ 13/1, Valikhanov str., Nur-Sultan, 010000, Kazakhstan \\ ${ }^{2}$ National Center for Biotechnology \\ 13/5, Korgalzhyn road, Nur-Sultan, 010000, Kazakhstan \\ ${ }^{3} L L P$ «Enbek» \\ Enbek village, Akmola region, Kazakhstan \\ dosova_alma@mail.ru
}

\begin{abstract}
Isolation and screening of new strains of lactic acid bacteria from the gut microbiome of carp and carp fingerlings were carried out. Morphological and cultural properties of isolates were studied. All isolates revealed high antagonistic activity against such opportunistic bacteria as Shewanella ximenensis AU 2R-1 BRKM 0724, Pseudomonas taiwanensis CB 2R-1 B-RKM 0726, Pseudomonas aeruginosa G13 B-RKM 0427, Aeromonas punctata G30 B-RKM 0287, Staphylococcus aureus B-RKM 0470, Escherichia coli B-RKM 0447. Based on the analysis of the nucleotide sequences of the $16 \mathrm{~S}$ rRNA gene fragment, 6 most active LAB cultures were identified, which belong to representatives of the genera Pediococcus, Lactobacillus and Leuconostoc. The procedure of depositing all strains in the Central Museum of Microorganisms of the Republican Collection of Microorganisms was carried out.

Key words: lactic acid bacteria, microbiome, antagonistic activity, isolation, DNA, nucleotide, gene.
\end{abstract}

\section{INTRODUCTION}

At the present time, the need for bactericidal and fungicidal drugs in the food industry, medicine and agriculture is growing every year. Currently used chemical preparations and antibiotics are toxic to humans and animals, accumulate in soil and water, moreover, among pathogenic and conditionally pathogenic microbes, the number of multi-resistant forms is growing.

The search for new natural antimicrobial substances synthesized by nonpathogenic microorganisms is an urgent task. Lactic acid bacteria (LAB) are widespread in nature: they can be found in soil, on decaying animal and plant residues, in the intestines of vertebrates, and in milk and dairy products. Together with plants and food, they enter the gastrointestinal tracts of humans and animals, making up its microbiota [1-3].

In modern conditions, fish farming technology has become a dynamically developing sector in the international market, accounting for about $25 \%$ of all world fish consumption. When breeding fish, both in natural and artificial reservoirs, one of the serious problems is the change in the microbiome of the aquatic environment and the 
formation of toxic compounds of the vital activity of microorganisms. Under these conditions, saprophytic microorganisms gain an advantage for growth and development, and bacterial, viral and fungal infections spread, which in turn leads to increased mortality of fish.

Classical microbiological and modern molecular genetic methods are a reliable and convenient tool for solving many applied problems in fish farming. Microbiological studies make it possible to isolate a pure culture of LAB, which can subsequently be used for precise studies, namely, PCR diagnostics of species-specific amplification. Accurate determination of the LAB species will make it possible in the future to create test systems (diagnostics) for the determination of infectious diseases by means of PCR analysis, and to develop promising probiotic preparations based on live active microorganisms.

\section{Materials and methods}

We used LAB isolates isolated in 2019 from the microbiome of carp underyearlings. The cultural and morphological characteristics of the isolated isolates were studied using the agar medium MRS of its own modification. When describing the cultural traits of bacteria, the shape of the colony, size, surface, profile, gloss, transparency, and color, edge of the colonies, structure and consistency were taken into account [4].

Collection conditionally pathogenic microorganisms Shewanella ximenensis AU 2R-1 B-RKM 0724, Pseudomonas taiwanensis CB 2R-1 B-RKM 0726, Pseudomonas aeruginosa G13 B-RKM 0427, Aeromonas punctata G30 B-RKM 0287, Staphylococcus aureus B-RKM 0470, Escherichia coli B-RKM 0447 were used to determine the antagonistic activity of LAB.

Antagonism was determined by diffusion into agar according to the diameter of the zone of no growth of test strains. For this, cell suspensions of the test strains were prepared in an amount of 1 billion / $\mathrm{ml}$ (according to the bacterial turbidity standard), applied to the surface of a Petri dish with an MPA medium, cut out wells $10 \mathrm{~mm}$ in diameter and filled them with the studied cultures $(0.1 \mathrm{ml}$ each $)$. The zones were measured after 48 hours, the results were taken into account without deducting the diameter of the well zone $[4,5]$.

DNA isolation was performed using the K. Wilson method [6], according to the standard protocol given in the "DNA Purification Kit" (Promega, USA) [7].

To determine the nucleotide sequence of the 16S pRNA gene, universal primers were used: forward 8F (5'-AGAGTTTGATCCTGGCTCAG-3 ') and reverse 806R (5'GGACTACCAGGGTATCTAAT3'). The PCR reaction was carried out in a total volume of $20 \mu \mathrm{l}$. The PCR mixture contained $150 \mathrm{ng}$ DNA, 5UTaqDNAPolymerase, 0.2 $\mathrm{mM}$ of each dNTPs, $10 \mathrm{x}$ Taq reaction buffer (ThermoFisher, USA), $2.5 \mathrm{mMMgCl} 2,10$ pmol of each primer.

Sequencing reactions were performed using BigDye ${ }^{\circledR}$ v 3.1 and primers. The reaction mixture was purified from unbound components with an acetate-alcohol mixture. Separation of gene fragments was performed using an automatic genetic analyzer. The obtained nucleotide sequence was compared with the nucleotide sequences of international databases - GenBank [8].

The construction of phylogenetic trees using the Mega 3.1 software, the alignment of nucleotide sequences was performed using the ClustalW algorithm, the construction of phylogenetic trees was carried out using the method of nearest neighbors (Neiighbor-Joining NJ).

\section{RESULTS}


6 Isolates were selected with good indicators of viability and growth on a nutrient medium.

Study of cultural and morphological characters. Studied the cultural and morphological characteristics of the selected isolates (table 1). The cultural properties were assessed by growth on agar medium followed by microscopy. As a result, it was found that 5 isolates are represented by gram-positive coccoid cells, among which there are mono- and diplococci, 1 isolate is represented by gram-positive rods with rounded ends. Disputes and capsules do not form.

Table 1. Cultural and morphological characteristics of isolated isolates from the intestines of carp and carp underyearlings

\begin{tabular}{|c|l|l|l|}
\hline Isolate name & \multicolumn{1}{|c|}{ Cultural and morphological features } & Gram painting & \multicolumn{1}{|c|}{$\begin{array}{c}\text { Growth at } \\
\text { MPA }\end{array}$} \\
\hline K 1 & $\begin{array}{l}\text { Colonies are milky, shiny, round, opaque, } \\
\text { smooth edges, medium, diameter 0.5 - 1.5 } \\
\text { mm. }\end{array}$ & $\begin{array}{l}\text { Cocci, Gram } \\
\text { positive }\end{array}$ & negatively \\
\hline K 2 & $\begin{array}{l}\text { Colonies are milky, shiny, round, opaque, } \\
\text { smooth edges, diameter 0.5 - 1 mm. }\end{array}$ & $\begin{array}{l}\text { Cocci, Gram } \\
\text { positive }\end{array}$ & negatively \\
\hline K 4 & $\begin{array}{l}\text { Colonies are milky, shiny, round, opaque, } \\
\text { smooth edges, diameter 0.5 - 1 mm. }\end{array}$ & $\begin{array}{l}\text { Cocci, Gram } \\
\text { positive }\end{array}$ & negatively \\
\hline C 1 & $\begin{array}{l}\text { Colonies are milky-beige, shiny, round, } \\
\text { opaque, smooth edges, small, diameter 0.5 - } \\
1 \text { mm. }\end{array}$ & $\begin{array}{l}\text { Sticks, Gram } \\
\text { positive }\end{array}$ & negatively \\
\hline C 4 (1) & $\begin{array}{l}\text { Colonies are milky-white, shiny, round, } \\
\text { opaque, smooth edges, small, diameter 0.5 - } \\
1.5 \text { mm. }\end{array}$ & $\begin{array}{l}\text { Cocci, Gram } \\
\text { positive }\end{array}$ & negatively \\
\hline C 4 (2) & $\begin{array}{l}\text { Colonies are light-beige, translucent, blurred, } \\
\text { edges are uneven and even, large, diameter } \\
1-3 \text { mm. }\end{array}$ & $\begin{array}{l}\text { Cocci, Gram } \\
\text { positive }\end{array}$ & negatively \\
\hline
\end{tabular}

Study of the antagonistic activity of LAB isolates. In order to create biopreparations with probiotic action, it is important that the bacteria that make up it have antimicrobial properties. To do this, we studied the antagonistic activity of the selected isolates of LAB (table 2).

Table 2. Antagonistic activity of new LAB isolates

\begin{tabular}{|c|c|c|c|c|c|c|}
\hline \multirow{2}{*}{$\begin{array}{l}\text { Isolate } \\
\text { name }\end{array}$} & \multicolumn{6}{|c|}{ Opportunistic strains } \\
\hline & Ps. aerug. & Sh.ximenen & St.aur. & E.coli & A.punct. & Ps. taiwan. \\
\hline K 1 & $20,0 \pm 0,82$ & $21,8 \pm 1,65$ & $18,5 \pm 0,65$ & $18,5 \pm 0,65$ & - & $16,3 \pm 0,63$ \\
\hline K 2 & $20,8 \pm 0,48$ & $18,5 \pm 1,19$ & $16,3 \pm 0,73$ & $15,3 \pm 1,31$ & - & $17,3 \pm 1,03$ \\
\hline K 4 & $23,8 \pm 1,25$ & $21,0 \pm 1,22$ & $16,8 \pm 0,63$ & $18,3 \pm 2,06$ & $11,0 \pm 0,41$ & $16,5 \pm 0,69$ \\
\hline $\mathrm{C} 1$ & $15,8 \pm 0,48$ & $21,3 \pm 0,85$ & $18,5 \pm 0,65$ & $15,3 \pm 0,63$ & - & $14,3 \pm 0,75$ \\
\hline C 2 & $18,3 \pm 0,25$ & $19,8 \pm 1,18$ & $18,5 \pm 0,65$ & $16,8 \pm 0,48$ & - & $26 \pm 1,35$ \\
\hline C 4 (1) & $11,3 \pm 0,48$ & - & - & - & - & $23,5 \pm 1,19$ \\
\hline C $4(2)$ & - & - & - & - & - & $25,5 \pm 0,65$ \\
\hline
\end{tabular}

*Note: The antagonistic activity of the studied cultures is considered zero when the width of the zone of no growth is up to $1.0 \mathrm{~mm}$, low - at $1.1-4.9 \mathrm{~mm}$, medium - at $5.0-8.9 \mathrm{~mm}$, high at $9.0 \mathrm{~mm}$ and more.

It was revealed that almost all isolates isolated from the intestinal microbiome of carp and common carp young of the year - K4, K1, K2, C1 - exhibit high antagonistic activity (from 11.3 to $26 \mathrm{~mm}$ ) with respect to the test strains used. Isolates C4 (1) and C4 (2) exhibited high antimicrobial activity against Bateria of the genus Pseudomonas. Isolate $\mathrm{K} 4$ showed a pronounced antagonism against $A$. punctata $(11.0 \pm 0)$.

Thus, the selected isolates exhibit high antagonistic activity with respect to one or another test strains. 
Study of the molecular genetic properties of LAB isolates. Molecular genetic properties of 6 active isolates were assessed by DNA isolation, PCR product preparation followed by sequencing and analysis of nucleotide sequences in the GenBank - BLAST program to determine the generic and species identification of microorganisms. The nucleotide sequences were analyzed and combined into a common sequence in SeqMan software (DNAStar). After that, the terminal fragments were removed (nucleotide sequences of primers, fragments with a low quality index). The resulting sequences were identified in GeneBank using the BLAST algorithm.

Taking into account the literature data [7], indicating the presence in international banks of nucleotide sequences Gene Bank (http://www.ncbi.nlm.nih.gov/), Ribosomal Data base Project (RDP-II) (http: // rdp.cme.msu.edu/html/), errors, we additionally built phylogenetic trees with $16 S$ rRNA nucleotide sequences of the gene of the reference strains of these species. The analysis included the nucleotide sequences of the $16 S$ rRNA gene, phylogenetically the most related microorganisms.

To construct phylogenetic trees, the software Mega 6 was used [9]. The ClustalW algorithm was used to align the nucleotide sequences; the trees were constructed using the (Neiighbor-JoiningNJ) method. Figure 1 shows a phylogenetic tree constructed on the basis of the analysis of the nucleotide sequences of the 16S rRNA gene from 4 strains K4, K2, K1, C4 (1), in which, when identified in BLAST, the maximum identity was to Pediococcus pentosaceus.

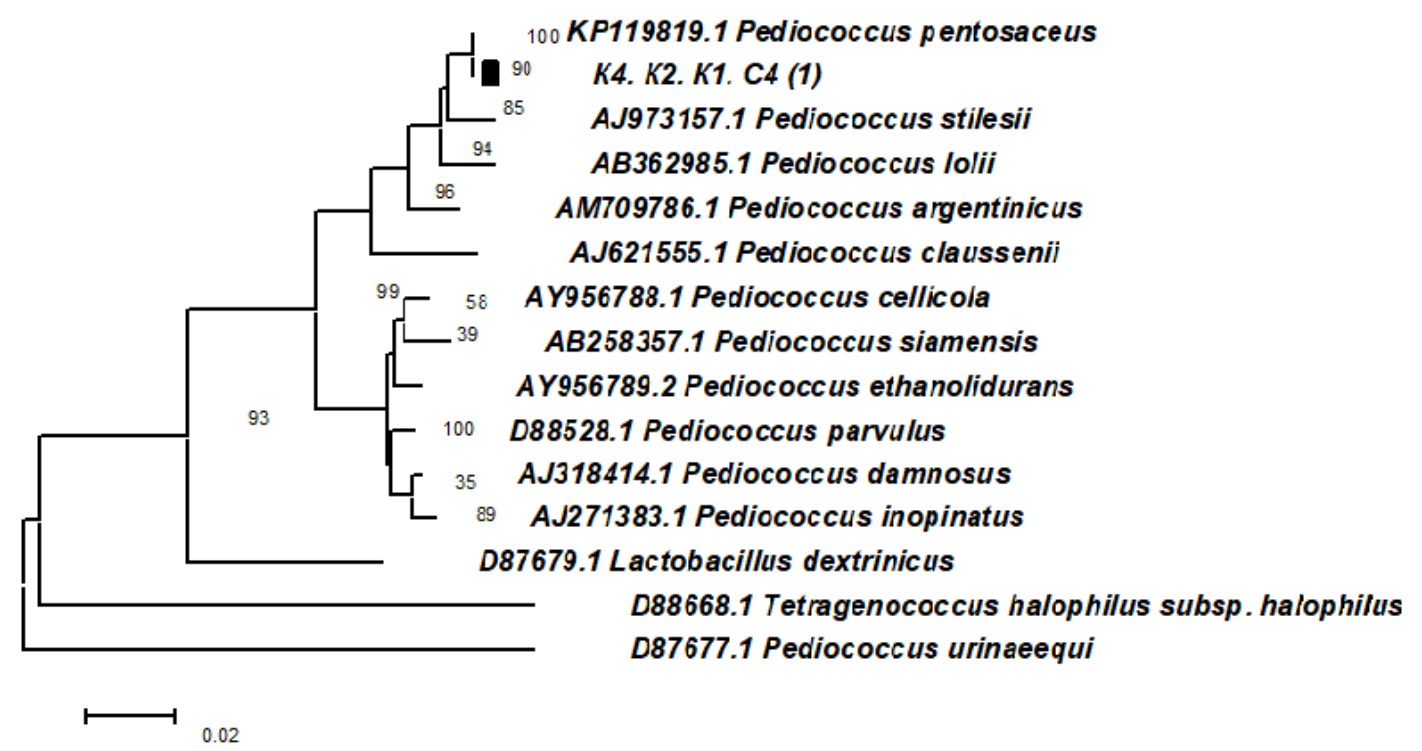

Fig. 1. Phylogenetic tree built on the basis of the analysis of the nucleotide sequence of the 16S rRNA gene of bacteria of the genus Pediococcus spp.

Figure 2 shows a phylogenetic tree constructed based on the analysis of the nucleotide sequences of the 16S rRNA gene from 1 strain $\mathrm{C} 1$, which, when identified in BLAST, had the maximum identity to Lactobacillus brevis. The nucleotide sequence from sample $\mathrm{C} 1$ is located on the same branch as Lactobacillus brevis. Taking into account the maximum percentage of coincidence of the analyzed sequence in the international database using the BLAST algorithm, as well as the results of phylogenetic analysis, it was established that this sample belongs to L. brevis. 


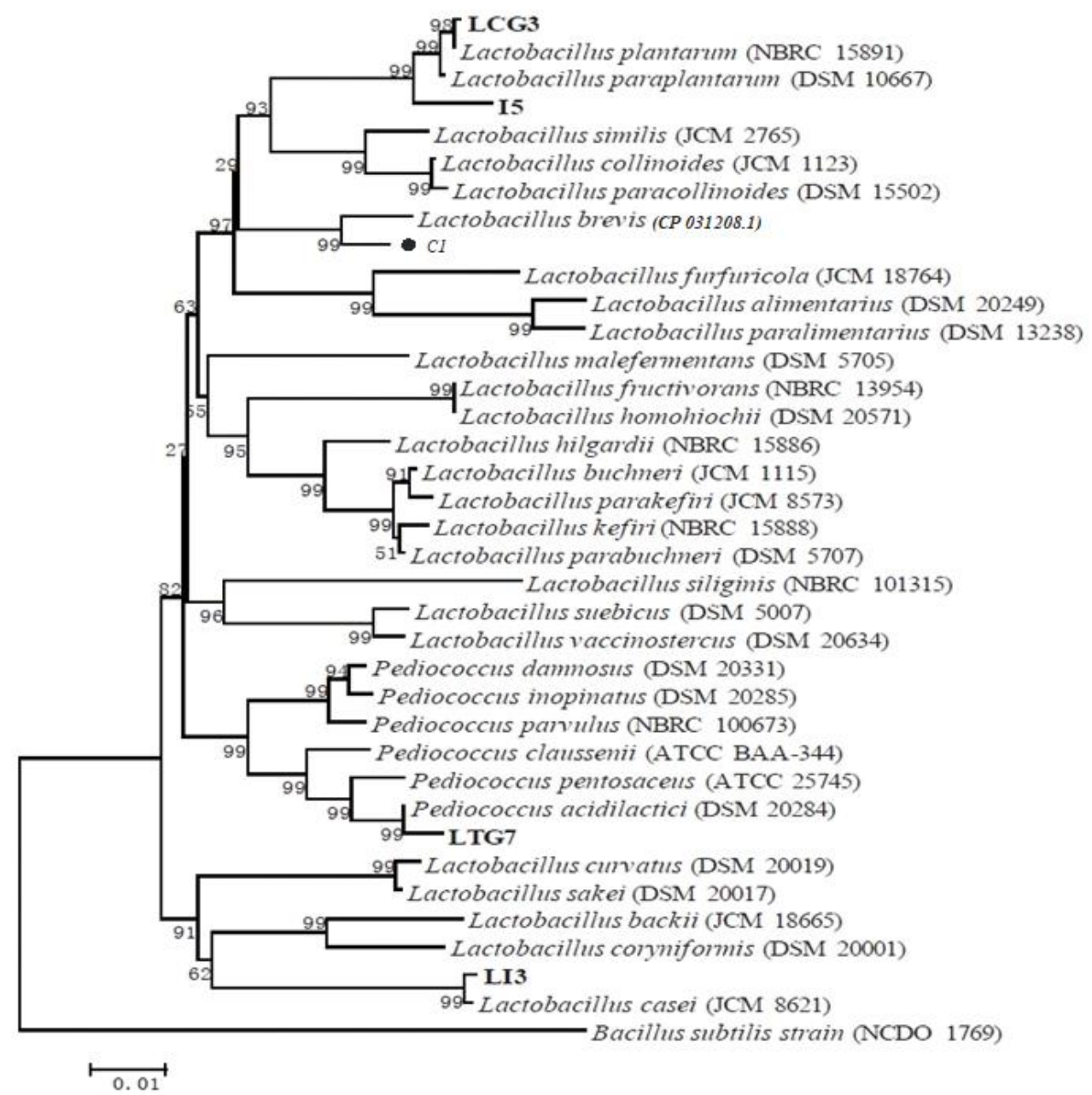

Fig.2. Phylogenetic tree constructed on the basis of the analysis of the nucleotide sequence of the 16S rRNA gene of bacteria of the genus Lactobacillus spp.

Figure 3 shows a phylogenetic tree constructed based on the analysis of the nucleotide sequences of the $16 \mathrm{~S}$ rRNA gene from 1 strain $\mathrm{C} 4$ (2), which, when identified in BLAST, had the maximum identity to Leuconostoc mesenteroides. The nucleotide sequence from sample C4 (2) is located on the same branch as Leuconostoc mesenteroides. Taking into account the maximum percentage of coincidence of the analyzed sequence in the international database according to the BLAST algorithm, as well as the results of phylogenetic analysis, it was found that this sample belongs to $L$. mesenteroides. 


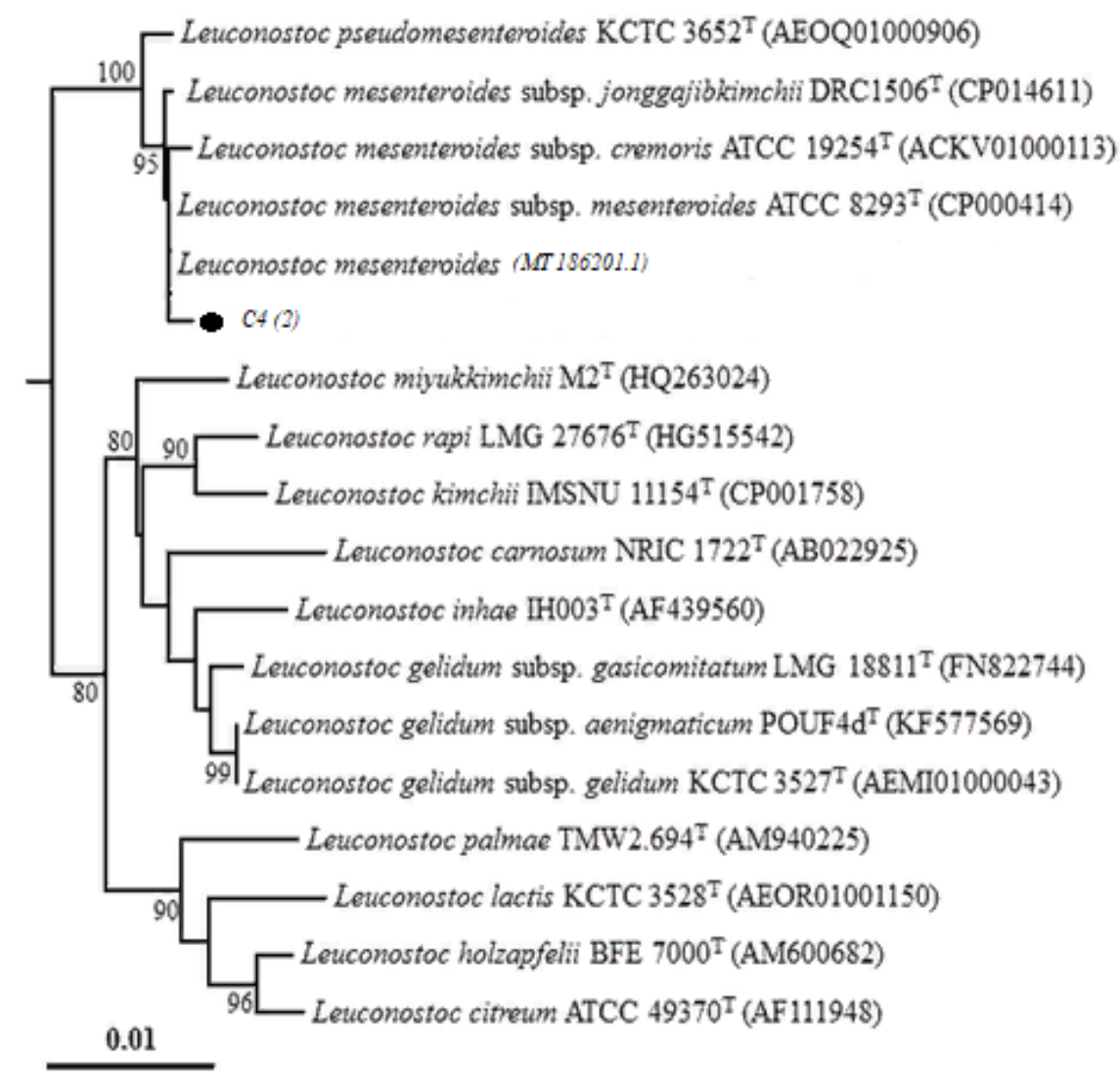

Fig. 3. Phylogenetic tree constructed based on the analysis of the nucleotide sequence of the 16S rRNA gene of bacteria of the genus Leuconostoc spp.

\section{DISCUSSION}

1. Six new isolates of LAB were selected, which were isolated from the intestinal microbiome of whitebait carp fish.

2. Studied morphological and cultural properties of new isolates. bacteria.

3. All isolates have high antagonistic activity against various opportunistic

4. Isolates $\mathrm{K} 4, \mathrm{~K} 2, \mathrm{~K} 1, \mathrm{C} 4$ (1) by $16 \mathrm{~S}$ rRNA nucleotide sequence analysis were identified as Pediococcus pentosaceus (percent identity from $98.97 \%$ to $99.34 \%$ ). Isolate C1 was identified as Lactobacillus brevis (percent identity 99.3\%), and isolate C4 (2) was identical to Leuconostoc mesenteroides (99.43\%).

5. The isolated strains of LAB were deposited in the Central Museum of Microorganisms of the Republican State Enterprise "Republican Collection of Microorganisms" of the SC MES RK.

Thus, the new strains of LAB are of scientific and practical interest in terms of expanding biological diversity, for making up various probiotic consortia that can be used not only in fish farming to improve the intestinal microflora of young fish, but also in the manufacture of lactic acid products. Possessing a high antimicrobial effect, this makes possible to use them as an alternative to antibiotics widely used in various fish diseases.

\section{Acknowledgements}

The work was supported by the Ministry of Education and Science of the Republic of Kazakhstan (grant AR05131929 "Technology for obtaining strains of active 
microorganisms of producers of a biological product alternative to antibiotics for the treatment and prevention of bacteriosis in fish" 2018-2020).

\section{REFERENCES}

1. Shenderov B.A. Funktsionalnoye pitaniye i yego rol v profilaktike metabolicheskogo sindroma [Functional nutrition and its role in the prevention of metabolic syndrome]. M.: DeLiprint, 2008. 319 p.

2. Broberg A., Jacobsson K., Ström K., Schnürer J. Metabolite Profiles of Lactic Acid Bacteria in Grass Silage. Applied and Environmental Microbiology, 2007, vol. 73, pp. 5547-5552.

3. Quinto E.J., Jiménez P., Caro I. et al. Probiotic Lactic Acid Bacteria: A Review. Food and Nutrition Sciences, 2014, vol. 5, pp. 1765-1775.

4. Workshop on microbiology: Textbook. manual for stud. higher. study. institutions / ed. A.I. Netrusova. - M.: Academy, 2005. - 608 p.

5. Saduakhasova S.A. Biological characteristics of Lactobacillus casei diss. ... Cand. biol. Sciences: 03.00.07. - Astana, 2008. - 103 p.

6. Wilson K. Preparation of genomic DNA from bacteria in Current Protocols in Molecular Biology / Eds. Ausubel F.M., Brent R., Kingston R.E., Moore D.D., Seidman J.G., Smith J.A. et al. - New York: Wiley, 1987, pp. 241-245.

7. Clarridge III J. E. Impact of $16 \mathrm{~S}$ rRNA Gene Sequence Analysis for Identification of Bacteria on Clinical Microbiology and Infectious Diseases. Clinical Microbiology Reviews, 2004, vol. 17, pp. 840-862.

8. Clayton R. A., Sutton G., Hinkle P. S., Bult Jr. C., Fields C..1995. Intraspecific variation in small-subunit rRNA sequences in GenBank: why single sequences may not adequately represent prokaryotic taxa. International Journal of Systematic Bacteriology, 1995, vol. 45, pp .595-599.

9. Kumar S., Tamura K., Nei M. MEGA3: Integrated software for Molecular Evolutionary Genetics Analysis and sequence alignment. Briefings in bioinformatics, 2004, vol. 5, no. 2, pp. 150-163.

\section{ЖАС ТҰҚЫ БАЛЫКТАРЫНЫН МИКРОБИОМАСЫНАН БӨЛІП АЛЫНҒАН ЖАНА СУТҚЫШҚЫЛДЫ БАКТЕРИЯЛАРЫНЫН ШТАМДАРЫН ИДЕНТИЯФИКАЦИЯЛАУ}

Текебаева Ж.Б. ${ }^{1}$, Бисенова Г.Н. ${ }^{1}$, Досова А.Д. ${ }^{1}$, Уразова М.С. ${ }^{1}$, Шевцов А.Б. ${ }^{2}$, Темірханов А.Ж. ${ }^{1}$, Ракишева А.К. ${ }^{3}$, Абжалелов А.Б. ${ }^{1}$, Сармурзина 3.C. 1

${ }^{1}$ Микроорганизмдердің республикалық коллекичиясы 13/1, Ш.Уалиханов көш., Нұр-Сұлтан, 010000, Қазақсстан

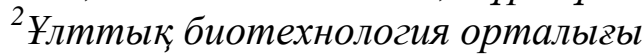

13/5, Қорвалжын тас жоль, Нұр-Сұлтан, 010000, Қазақстан

${ }^{3}$ ЖШС «Еңбек»

Еңубек ауылы, Ақмола облысы, Қазақустан

dosova_alma@mail.ru 


\section{ТYЙІН}

Жас тұқы және сазан ішектерінен (ересектерден) оқшауланған сүт қышқылды бактериялардың жаңа штамдарын бөліп алу жұмысы және олардың скринингі жүргізілді. Оқшауланған сүтқышқылды бактериялардын изоляттарының морфологиялық және мәдени қасиеттері, антагонистік белсенділігі анықталды. Барлық изоляттарың Shewanella ximenensis AU 2R-1 B-RKM 0724, Pseudomonas taiwanensis CB 2R-1 B-RKM 0726, Pseudomonas aeruginosa G13 B-RKM 0427, Aeromonas punctata G30 BRKM 0287, Staphylococcus aureus B-RKM 0470, Escherichia coli B-RKM 0447 сияқты шартты-патогенді бактерияларға қатысты жоғары антагонистік белсенділігі бар екені анықталды. 16S rRNA генінің фрагментінің нуклеотидтік тізбегін талдау негізінде ең белсенді 6 СҚБ дақылдары Pediococcus, Lactobacillus и Leuconostoc түріне жататыны анықталды.Микроорганизмдердің республикалық коллекциясы Орталық микроорганизмдер мұражайына барлық штаммдардына депонирлеу рәсімі өткізілді.

Негізгі сөздер: сүт қышқылы бактерия, микробиом, антагонистік белсенділік, оқшаулау, ДНҚ, нуклеотид, ген.

\section{ВЫДЕЛЕНИЕ И ИДЕНТИФИКАЦИЯ НОВЫХ ШТАММОВ МОЛОЧНОКИСЛЫХ БАКТЕРИЙ ИЗ МИКРОБИОМА МОЛОДИ КАРПОВЫХ РЫБ}

Текебаева Ж.Б. ${ }^{1}$, Бисенова Г.Н. ${ }^{1}$, Досова А.Д. ${ }^{1}$, Уразова М.С. ${ }^{1}$, Шевцов А.Б. ${ }^{2}$ Темирханов А.Ж. ${ }^{1}$, Ракишева А.К. ${ }^{3}$, Абжалелов А.Б. ${ }^{1}$, Сармурзина 3.C. ${ }^{1}$

${ }^{1}$ Республиканская коллекция микроорганизмов

ул. Ш. Уалиханова, 13/1, Нур-Султан, 010000, Казахстан

${ }^{2}$ Национальный изентр биотехнологии

Коргалжынское шоссе, 13/5, Нур-Султан, 010000, Казахстан

${ }^{3}$ ТОО «Енбек», с. Енбек, Акмолинская область, Казахстан

dosova_alma@mail.ru

\section{АБСТРАКТ}

Проведено выделение новых штаммов молочнокислых бактерий из микробиома кишечника сеголеток карпа и сазана. Изучены морфологические и культуральные свойства изолятов. Выявлено, что все изоляты обладают высокой антагонистической активностью по отношению к таким условно-патогенным бактериям как: Shewanella ximenensis AU 2R-1 B-RKM 0724, Pseudomonas taiwanensis CB 2R-1 B-RKM 0726, Pseudomonas aeruginosa G13 B-RKM 0427, Aeromonas punctata G30 B-RKM 0287, Staphylococcus aureus B-RKM 0470, Escherichia coli B-RKM 0447. На основе анализа нуклеотидных последовательностей фрагмента гена $16 \mathrm{~S}$ рРНК идентифицированы 6 наиболее активных культур молочнокислых бактерий, которые относятся к представителям родов Pediococcus, Lactobacillus и Leuconostoc. Проведена процедура депонирования всех штаммов в Центральном музее микроорганизмов Республиканской коллекции микроорганизмов. 
Ключевые слова: молочнокислые бактерии, микробиом, антагонистическая активность, ДНК, нуклеотид, ген. 
